\title{
Analisis Profesionalisme Anggota DPRD dalam Pelaksanaan Fungsi Legislasi di Kota Depok
}

\author{
Muh. Kadarisman. \\ Dosen Universitas Muhammadiyah Jakarta \\ Jl. KH. Ahmad Dahlan, Ciputat-Jakarta Selatan 15419 \\ kadarisman.bkn@gmail.com
}

\begin{abstract}
This research is aimed to analyze the professionalism of legislative member at regional level in Depok in the implementation of legislative function. It uses a descriptive method using the empirical law approach. The result of the research shows that: first, professionalism of the legislative members related to their legislative function has well run as reflected from the performance supported by sufficient science, commitment for the promise, respect to social values, being obedient for the regulations, dedication to public interest, being persistent in following the development of science he or she focuses on, being skillful in problem-solving and controlling the local government well. Second, the implementation of legislative function runs well both in the implementation of representative function, prompting a responsive local regulation, and debate function that is maximally done.
\end{abstract}

Key words : Professionalism, legislative function, local government

\begin{abstract}
Abstrak
Tulisan ini hendak menganalisis tentang profesionalisme Anggota DPRD Depok dalam pelaksanaan fungsi legislasi. Metode yang digunakan secara deskriptif dengan pendekatan hukum empiris. Hasil penelitian: pertama, profesionalisme anggota dewan terkait fungsi legislasi telah berjalan baik, ditunjukkan oleh kinerja dengan dukungan ilmu pengetahuan yang memadai, komitmen pada janji, menghormati nilai sosial yang berlaku, menaati peraturan yang sah, mendarmabaktikan profesinya untuk kepentingan masyarakat, tekun mengikuti perkembangan IImu yang dimiliki, terampil memecahkan persoalan, serta menjalankan pengawasan jalannya pemerintahan daerah dengan baik. Kedua, pelaksanaan fungsi legislasi berjalan baik, berupa pelaksanaan fungsi representatif, menghasilkan perda yang responsif, serta fungsi debat telah dijalankan secara maksimal.
\end{abstract}

Kata Kunci : Profesionalisme, fungsi legislasi, pemerintahan daerah 


\section{Pendahuluan}

Tugas utama setiap Anggota Dewan Perwakilan Rakyat Daerah (DPRD) Kota Depok pada era reformasi adalah sebagai wakil rakyat atau jelmaan seluruh masyarakat Kota Depok, wajib memberikan pelayanan publik secara maksimal serta modern kepada masyarakat yang beragam dan dinamis. Oleh karena itu, untuk mencapai kinerja tinggi bagi setiap Anggota DPRD tersebut diperlukan profesionalisme yang tinggi pula.

Efektivitas implementasi penyelenggaraan asas desentralisasi saat ini, adalah sebagaimana diatur dalam Pasal 18 ayat (1) Undang-Undang Dasar (UUD) 1945 yaitu “Negara Kesatuan Republik Indonesia dibagi atas daerah-daerah provinsi, kabupaten dan kota, yang tiap-tiap provinsi, kabupaten dan kota itu mempunyai pemerintah daerah yang diatur dengan undang-undang". Dalam Pasal 18 ayat (3) UUD 1945 dijelaskan sebagai berikut, "Pemerintah daerah provinsi, daerah kabupaten dan kota memiliki Dewan Perwakilan Rakyat Daerah (DPRD) yang anggota-anggotanya dipilih melalui pemilihan umum". Berdasarkan uraian tersebut, jelas bahwa pembentukan DPRD Kabupaten maupun Kota di Indonesia adalah sejalan dengan kehendak UUD 1945. ${ }^{1}$ Begitu pula di Kota Depok, penyelenggaraan pemerintahan daerah ini perlu mengikutsertakan dan memberdayakan seluruh rakyat melalui wakil-wakilnya yang duduk di DPRD. Pembentukan DPRD Kota Depok, pada hakekatnya didasarkan pada prinsip sistem pemerintahan yaitu daerah mempunyai kewenangan untuk mengurus rumah tangganya sendiri. UndangUndang (UU) No. 32 Tahun 2004 tentang Pemerintahan Daerah telah menegaskan berkaitan dengan fungsi legislasi DPRD tersebut. Oleh karena itu, untuk mengurus rumah tangganya sendiri, maka di Kota Depok juga memerlukan penajaman fungsi legislasi DPRD-nya.

Dalam lembaga DPRD Kota Depok tersebut, para wakil rakyat bekerja merumuskan kebijakan daerah atas nama pemilihnya, serta menggerakkan seluruh potensi masyarakat dalam proses ekonomi, politik, sosial budaya, hukum, keamanan, pemerintahan dan pembangunan. DPRD Kota Depok yang terdiri atas para anggota-anggotanya yang mewakili rakyat pemilih, adalah pemegang kedaulatan di bidang legislatif di Kota Depok bersama dengan Pemerintah Daerah

${ }^{1}$ Bagir Manan, Asas-Asas Pembentukan Peraturan Perundang-Undangan yang Baik, RajaGrafindo Persada, Jakarta, 2009, hlm. 29. 
(Pemda) Kota Depok. Dalam kaitan ini, Pemda Kota Depok sebagai pihak eksekutif di daerah, tidak lagi bertanggung jawab kepada DPRD. Namun, dalam kenyataan menunjukkan bahwa peran dan fungsi DPRD sebagaimana digariskan dalam peraturan perundang-undangan, belum terlaksana dengan baik dan maksimal sesuai harapan publik. Kondisi DPRD Kota Depok yang demikian, dalam beberapa tahun terakhir bersamaan dengan bergulirnya arus reformasi, maka tuntutan atas pemberdayaan DPRD Kota Depok dalam sistem pemerintahan daerah semakin meningkat.

Tuntutan masyarakat sebagai konsekuensi negara hukum tersebut, secara konstitusional terwujud dengan lahirnya Ketetapan MPR Nomor XV/MPR/1988 yang ditindaklanjuti dengan berlakunya UU No. 32 Tahun 2004 tentang Pemerintahan Daerah. ${ }^{2}$ Pemisahan secara tegas antara Kepala Daerah sebagai lembaga eksekutif dengan DPRD sebagai badan legislatif daerah, pada asasnya telah memberikan kedudukan yang kuat dan ruang lingkup yang luas kepada DPRD dalam penyelenggaraan pemerintahan daerah. Selain hal tersebut, DPRD mempunyai kekuasaan mengawasi eksekutif daerah berdasarkan hak-hak yang dimilikinya. Jika hak-hak tersebut dimanfaatkan secara maksimal, maka akan meningkatkan kinerja Pemerintah Daerah dan kinerja Anggota DPRD serta memperbaiki citra DPRD di mata rakyatnya. ${ }^{3}$ Dengan demikian, DPRD sebagai badan legislatif daerah yang terdiri atas para anggota yang mewakili partai politik yang ada, harus mampu menempatkan dirinya sebagai lembaga yang menjadi sumber inisiatif dan prakarsa masyarakat setempat yang semakin kritis dan modern.

Adanya hak dan kewenangan kepada Anggota DPRD Kota Depok yang luas, adalah bukti bahwa upaya demokratisasi pemerintahan di Kota Depok semakin menunjukkan bentuk yang nyata, transparan, dan akuntabel. Wewenang yang luas dan nyata oleh Anggota DPRD Kota Depok tersebut, harus dilaksanakan secara sungguh-sungguh dan profesional guna menghindari dominasi kekuatan eksekutif terkait semakin luasnya otonomi yang diberikan kepada daerah. Keberhasilan Anggota DPRD Kota Depok dalam menjalankan tugas dan fungsinya, merealisasikan janji-janjinya saat kampanye, sangat tergantung kepada sejauh mana tingkat kemampuan profesionalismenya dalam mengemban amanah mulia,

\footnotetext{
28.

${ }^{2}$ Azhari, Negara Hukum Indonesia, Analisis Yuridis Normatif tentang Unsur-Unsurnya, UI Press, Jakarta, 1995, hlm.

${ }^{3}$ Bagir Manan, Menyongsong Fajar Otonomi Daerah, Pusat Studi Fakultas Hukum UII, 2001, hlm. 35
} 
wewenang serta hak-haknya. Secara normatif, hal mendasar yang membedakan antara UU No. 32 Tahun 2004 dengan UU No. 5 Tahun 1974 adalah pemberdayaan secara struktural lembaga legislasi daerah. ${ }^{4}$

Penyusunan kebijaksanaan daerah yang tepat dan pro rakyat, selain tergantung pada kewenangan apa yang dimiliki, juga memerlukan kegigihan, tekad, serta dedikasi tinggi dari para Anggota Dewan guna memecahkan berbagai persoalan yang dihadapi warganya juga dalam rangka merebut hati pemilihnya untuk pemilu ke depan. Dengan demikian, profesionalisme yang dimiliki Anggota DPRD Kota Depok, baik dari segi pendidikan, pengalaman, kemampuan, keterampilan dan perilaku kerja adalah sangat penting untuk dipenuhi agar mampu mengimbangi kemampuan sumber daya manusia (SDM) yang ada pada pihak eksekutif daerah. Optimalisasi fungsi dan tugas Anggota DPRD Kota Depok, sangat tergantung pada sejauh mana peran yang dimainkan oleh para Anggota DPRD dalam mengemban amanah rakyat.

Optimalisasi peran Anggota DPRD, sangat ditentukan oleh kualitas dan kuantitas pengabdian para Anggota DPRD itu tersebut. ${ }^{5}$ Oleh karena tuntutan rakyat yang semakin tinggi dan cerdas tersebut, salah satu upaya yang harus dilakukan oleh para Anggota Dewan adalah dengan meningkatkan kemampuan profesionalisme atau kompetensinya agar tidak hanya piawai dalam berpolitik, namun juga memiliki pengetahuan, kemampuan, keterampilan serta moral yang memadai terkait konsepsi serta teknis penyelenggaraan pemerintahan, mekanisme kerja kelegislatifan, kebijakan publik, teknis pengawasan, penyusunan anggaran dan lain-lain. Pemberdayaan DPRD Kota Depok diharapkan dapat menciptakan mekanisme check and balance yang lebih efektif antara kekuasaan eksekutif dan legislatif di daerah. ${ }^{6}$

Dalam melaksanakan berbagai aspek fungsinya, kinerja DPRD Kota Depok masih menunjukkan kecenderungan kurang optimal. ${ }^{7}$ Misalnya, dalam pembuatan Perda Kota Depok sebagai produk hukum DPRD yang menyangkut kepentingan publik, dominasi eksekutif masih kuat. Hal tersebut terbukti bahwa sebagian besar rancangan Perda Kota Depok yang diajukan ke DPRD Kota Depok untuk dibahas,

\footnotetext{
${ }^{4}$ Muh. Kadarisman, Pemberdayaan terhadap Kinerja Anggota DPRD Kota Depok, dalam Jurnal Mimbar Hukum UGM, Vol. 24 Nomor 2, Juni 2012, hlm. 300.

${ }^{5}$ HAW Widjaja, Penyelenggaraan Otonomi di Indonesia dalam Rangka Sosialisasi UU No. 32 Tabun 2004 tentang Pemerintahan Daerah, RajaGrafindo Persada, Jakarta, 2005, hlm. 43.

${ }^{6} \mathrm{Ibid}$, hlm. 300.

${ }^{7}$ Ibid, hlm. 301.
} 
berasal dari inisiatif Pemerintah Daerah. Hal ini menunjukkan bahwa pelaksanaan fungsi legislasi DPRD Kota Depok dalam hal inisiatif mengajukan rancangan (menampung dan menuangkan aspirasi masyarakat dalam konsep Rancangan Perda) belum sebanding dengan Raperda yang lahir dari pemerintah/eksekutif Kota Depok. ${ }^{8}$ Dalam hak amandemen yang dimiliki DPRD, penggunaannya juga masih sangat rendah, dan sebagian besar Raperda yang diajukan pihak eksekutif lolos dalam pembahasan serta akhirnya mendapat pengesahan menjadi Perda Kota Depok.

Terkait dengan fungsi pengawasan atas pelaksanaan kebijakan daerah, Perda maupun pelaksanaan APBD, hak-hak DPRD yang mencerminkan fungsi pengawasan misalnya hak untuk mengadakan penyelidikan (hak angket), hak meminta keterangan (hak interpelasi), dan hak mengajukan pernyataan pendapat serta hak mengajukan pertanyaan, juga belum digunakan secara optimal oleh DPRD Kota Depok. Begitu pula, sorotan kritis terhadap berbagai permasalahan seiring dengan keradaan DPRD sebagai badan legislatif dan pengawas eksekutif, berasal dari berbagai lapisan masyarakat yang terwujud dalam bentuk aksi turun ke jalan sebagai akibat atas ketidakpuasan masyarakat terhadap pelaksanaan kebijakan Pemda Kota Depok yang ditujukan kepada DPRD Kota Depok. Permasalahan lain terkait kedudukan DPRD Kota Depok sebagai wakil rakyat, masyarakat menilai bahwa DPRD masih perlu secara maksimal memperjuangkan aspirasi rakyat yang diwakilinya. ${ }^{9}$

\section{Rumusan Masalah}

Rumusan masalah dalam penelitian ini adalah: pertama, bagaimana profesionalisme Anggota DPRD Kota Depok dalam pelaksanaan fungsi legislasi ? Kedua, pelaksanaan fungsi legislasi Anggota DPRD Kota Depok dan Pemerintah Kota Depok?

\section{Tujuan Penelitian}

Tujuan dalam penelitian ini adalah untuk, pertama, memahami dan menganalisis profesionalisme Anggota DPRD Kota Depok dalam pelaksanaan fungsi legislasi. Kedua, menganalisis pelaksanaan fungsi legislasi Anggota DPRD Kota Depok dan Pemerintah Kota Depok.

\footnotetext{
${ }^{8}$ Achmad Ruslan, Pembentukan Perundang-undangan yang Berkualitas,Handout, Tidak Diterbitkan, 2006, hlm. 52. ${ }^{9}$ Winarno Surahmad, Metodologi Research-1, Alumni, Bandung, 1983, hlm. 34.
} 


\section{Metode Penelitian}

Penelitian ini termasuk penelitian deskriptif, karena untuk mendeskripsikan secara riil tentang sejauh mana profesionalisme Anggota DPRD Kota Depok terkait pelaksanaan fungsi legislasi dengan menggunakan pendekatan hukum empiris. ${ }^{10}$ Penelitian ini dilangsungkan di Kantor DPRD Kota Depok dan Pemerintah Kota (Pemkot) Depok tepatnya pada Unit Kerja Asisten Tata Praja. Dalam penelitian tersebut, peneliti menangkap serta merumuskan fenomena terkait fokus penelitian guna mendapatkan keadaan secara objektif. Selanjutnya, sebagai sumber bahan hukum dalam penelitian ini meliputi: pertama, bahan hukum primer, yaitu bahan yang didapatkan secara langsung di lapangan dari nara sumber yang terkait langsung dengan substansi penelitian. Sebagai sumber informasi dalam penelitian ini adalah para Anggota DPRD Kota Depok sebanyak 50 Anggota Dewan, dan secara Purposive Random Sampling ditetapkan 10 Anggota Dewan (Informan I sampai dengan Informan X).

Sepuluh Informan tersebut adalah dari Partai Demokrat sebanyak 3 orang, Partai Keadilan Sejahtera sebanyak 2 orang, Partai Golkar sebanyak 2 orang, PDI Perjuangan 1 orang, Partai Gerindra sebanyak 1 orang, PAN sebanyak 1 orang, P-3 sebanyak 1 orang, Partai Kebangkitan Bangsa sebanyak 1 orang, dan Partai Damai Sejahtera sebanyak 1 orang. Selanjutnya, ditambah dengan Informan dari pihak eksekutif yaitu karyawan dari Asisten Tata Praja sebanyak 2 orang Informan (Informan XI dan Informan XII). Kedua, bahan hukum dasar sekunder, meliputi bahan yang bersumber dari referensi, jurnal, serta berbagai peraturan perundang-undangan. Ketiga, bahan hukum tersier, meliputi bahan hukum yang memberikan petunjuk atau penjelasan atas bahan hukum primer dan sekunder. ${ }^{11}$

Terkait dengan pengumpulan bahan hukum sebagai data dalam penelitian ini, dilakukan dengan penelitian lapangan (field research). Dalam mendapatkan data atau informasi terkait objek penelitian ini, Peneliti secara langsung berhubungan baik dengan individu Anggota DPRD Kota Depok maupun dengan lembaganya khususnya Sekretariat DPRD Kota Depok serta pihak Pemkot Depok khususnya Asisten Tata Praja yang bersedia memberikan data atau informasi terkait dengan substansi penelitian.

Instrumen yang digunakan dalam pengumpulan data adalah 1) dokumentasi, yaitu terkait dengan bahan-bahan tertulis antara lain dokumen-dokumen, literatur, arsip dan

\footnotetext{
${ }^{10}$ Marbun BN, DPR Pertumbuhan dan Cara Kerjanya, Pustaka Sinar Harapan, Jakarta, 2006, hlm. 158.

${ }^{11}$ Ibid, hlm. 54.
} 
dokumen lainnya sesuai substansi penelitian. 2) wawancara, yaitu dengan melakukan tanya jawab dengan para Informan yaitu para Anggota DPRD Kota Depok, beberapa staf Sekretariat DPRD, serta pihak Pemerintah Kota Depok khususnya Asisten Tata Praja. Proses wawancara dengan telah disiapkan terlebih dahulu pedoman wawancara, sehingga didapatkan data atau informasi secara akurat dan lengkap. 3) observasi, yaitu dengan melakukan pengamatan langsung di lokasi penelitian baik terhadap kinerja Anggota Dewan maupun pihak mitra kerjanya yaitu Pemerintah Kota Depok.

Selanjutnya, analisis bahan hukum dalam penelitian ini menggunakan pendekatan normatif. ${ }^{12}$ Hal tersebut disebabkan mendasarkan pada peraturan perundang-undangan, atau hukum dikonsepkan sebagai norma yang merupakan patokan berperilaku manusia yang pantas dilakukan. Juga digunakan data sekunder yang meliputi bahan hukum primer, bahan hukum sekunder, serta bahan hukum tersier yang meliputi bahan hukum yang memberi petunjuk atau penjelasan atas bahan hukum primer dan sekunder, misalnya kamus besar Bahasa Indonesia. ${ }^{13}$

\section{Hasil Penelitian dan Pembahasan}

\section{Profesionalisme Anggota DPRD Kota Depok}

Profesionalisme Anggota DPRD tersebut dibangun atas sikap profesionalisme dalam bekerja dan sikap profesionalisme dalam keseharian hidupnya.

\section{Sikap Profesionalisme Anggota DPRD Kota Depok dalam Bekerja}

Indikator pertama dalam sikap profesionalisme Anggota DPRD ini adalah perilaku yang didukung ilmu pengetahuan. Dalam menjalankan tugas sebagai wakil rakyat, Anggota Dewan menyuarakan aspirasi masyarakat tersebut dalam berbagai forum, di antaranya adalah dalam forum menjalankan fungsi legislasi yaitu bersama dengan Pemkot Depok merumuskan berbagai ketentuan peraturan perundangundangan untuk kepentingan daerah. Dalam konteks penelitian ini, ilmu pengetahuan para Anggota Dewan dan pihak Pemkot Depok tersebut adalah segala sesuatu yang diketahui terkait dengan tugas, fungsi, tanggung jawab dan wewenang yang harus diemban. Hasil wawancara dengan Informan I, II, dan III didapatkan penjelasan sebagai berikut.

\footnotetext{
${ }^{12}$ Sudikno Mertodikusumo, Mengenal Hukum Suatu Pengantar, Yogyakarta, Liberty, 2003, hlm. 41.

${ }^{13}$ Bagir Manan, Beberapa Masalah Hukum Tata Negara Indonesia, Alumni, Bandung, 1993, hlm. 15.
} 
"Ilmu pengetahuan berupa pikiran cerdas terkini dan ke depan (visioner) para Anggota Dewan tersebut dapat dipelihara antara lain melalui berbagai bentuk pengajaran. Dengan demikian pekerjaan menyebarluaskan atau mengimplementasikan ilmu yang dimiliki para Anggota DPRD Kota Depok tersebut merupakan tindakan yang sangat terhormat. Juga sangat penting bagi Anggota Dewan yang telah mendapatkan ilmu pengetahuan tersebut, selanjutnya mengajarkan kembali kepada orang lain termasuk masyarakat terkait dengan peningkatan kemampuan profesionalisme Anggota Dewan dalam menjalankan fungsi legislasi".

Indikator ilmu pengetahuan di sini adalah kemampuan para Anggota Dewan mencurahkan pemikiran-pemikiran baru yang diketahuinya sesuai beban tugas dan tanggung jawab atas amanah rakyat yang diemban. Terkait dengan indikator pengetahuan dalam profesionalisme tersebut, Herman menjelaskan bahwa suatu pekerjaan (an occupation) dapat disebut profesi apabila pekerjaan itu sendiri mencerminkan adanya dukungan yang berupa ciri-ciri pengetahuan (intellectual character), diabdikan untuk orang lain, keberhasilan pekerjaan tersebut bukan didasarkan pada keuntungan financial, didukung oleh adanya organisasi (asosiasi) profesi yang antara lain menentukan berbagai ketentuan yang merupakan kode etik, dan ditentukan adanya standar kualifikasi profesi. ${ }^{14}$

Indikator ini, lebih merujuk kepada pemahaman atau penguasaan kognitif tentang berbagai aspek yang berkaitan dengan tugas dan fungsinya, baik dasar filosofi maupun mekanisme atau prosedur dalam pelaksanaan tugas dan fungsi legislasi sebagai wakil rakyat. Pengertian tersebut menunjukkan bahwa profesi pada hakekatnya merupakan jenis tugas, pekerjaan, jabatan, dan ada pula yang mengatakan occupation, area of activity. Hasil observasi menunjukkan bahwa ternyata masih terdapat Anggota DPRD Kota Depok yang belum atau kurang memahami bahwa ilmu pengetahuan yang telah dimiliki tersebut penting untuk didistribusikan/disebarluaskan dan diajarkan melalui berbagai kesempatan dan aksi sosial kepada masyarakat luas.

Dengan demikian tercipta masyarakat yang cerdas dan berilmu pengetahuan modern, masyarakat yang berdaya dan berakhlak mulia. Hasil wawancara dengan Informan IV, dan V mengemukakan sebagai berikut.

“Kami sebagai Anggota Dewan di Kota Depok yang dibekali ilmu pengetahuan yang dipelajari dan dimilikinya, serta harus mampu mengimplementasikannya

${ }^{14}$ Herman, "Analisis terhadap Faktor-faktor yang Mempengaruhi Profesionalisme PNS", makalah, Puslitbang BKN, Jakarta, 2003, hlm. 10. 
atau mengajarkan pemikiran atau konsep terbaru tersebut pada tugas nyata maupun fungsi yang diemban sebagai wakil rakyat dalam memperjuangkan aspirasi masyarakat terutama dalam menjalankan fungsi legislasi kepada mitra kerjanya yaitu Pemkot Depok. Senantiasa perlu mengikuti perkembangan ilmu pengetahuan yang sangat dinamis, sehingga menumbuhkan pemikiran baru secara kreatif/inovatif sesuai dengan kebutuhan dan tantangan tugas".

Mokoginta menjelaskan bahwa profesionalisme dapat pula berarti sebagai paham yang menempatkan profesi sebagai titik perhatian utama dalam hidup seseorang. Ini berarti bahwa orang yang menganut paham profesionalisme selalu menunjukkan sikap profesional dalam bekerja dan di dalam keseharian hidupnya. Demikian halnya dengan makna profesional seseorang tidak hanya semata-mata diukur dari kemampuan (knowledge) dan keterampilan (skills) yang dimiliki, tetapi faktor etika atau moral (attitude) juga masuk di dalamnya. ${ }^{15}$

Hasil observasi menunjukkan bahwa ternyata belum semua Anggota Dewan di kota Depok mampu mengimplementasikan ilmu pengetahuan yang dimilikinya untuk kemaslahatan masyarakat. Dengan demikian, penting diciptakan kemampuan bagi masing-masing Anggota DPRD, untuk mengimplementasikan ilmu pengetahuan yang dimiliki tersebut dalam rangka mencerdaskan masyarakat di Kota Depok. Selain Anggota Dewan yang berpengetahuan tinggi dan cerdas serta profesional dalam menjalankan fungsi legislasi, juga mitra kerjanya yaitu pihak eksekutif (Aparat Pemkot Depok) dituntut peningkatan pengetahuannya, sehingga secara bersama-sama memiliki ilmu pengetahuan modern dan cerdas serta secara bersama-sama bertanggung jawab dan mendukung pencapaian kesejahteraan masyarakat di kota Depok.

Selanjutnya kepada Informan VI, VII, VIII, dan IX diajukan pertanyaan berkaitan dengan sikap profesionalisme Anggota Dewan bisa dicapai dengan memiliki kompetensi di bidangnya sebagai indikator ke dua dari sikap profesionalisme tersebut. Hasil jawaban informan dapat dikemukakan sebagai berikut.

“Profesionalisme kami sebagai Anggota DPRD Kota Depok dapat dicapai dengan ilmu pengetahuan berupa memiliki kompetensi di bidangnya. Dalam konteks ini kompetensi Anggota Dewan baik sebagai bentuk kemampuan umum (general ability) maupun sebagai kemampuan khusus (specific ability), tentu tidak dengan sendirinya diperoleh dalam diri Anggota Dewan, namun didapatkan dengan memberikan ruang gerak agar kompetensi tersebut berkembang. Dengan demikian, tinggi rendahnya kompetensi Anggota Dewan di daerah dipengaruhi

${ }^{15}$ Urip A. Mokoginta, "Konsep dan Pengalaman LPT UI dalam Rekrutmen Pegawai", Laporan Hasil Diskusi Panel Reformasi Kepegawaian, Pusat Penelitian dan Pengembangan BKN, Jakarta, 2002, hlm. 4. 
secara timbal balik oleh berbagai faktor yang terdapat dalam lingkungan organisasi, baik lingkungan internal maupun eksternal".

Selanjutnya, kepada informan diajukan pertanyaan tentang profesionalisme Anggota DPRD dapat dicapai dengan pengetahuan berupa ketekunan mengikuti perkembangan ilmu yang dimiliki. Hasil wawancara dengan Informan II, IV, V, VIII, IX, dan X mengemukakan bahwa pentingnya para Anggota Dewan untuk secara terus menerus mengikuti perkembangan ilmu yang dimiliki, sehingga ilmu pengetahuan tersebut mampu menjawab permasalahan yang berkembang dinamis di masyarakat. Namun sebaliknya, apabila ilmu pengetahuan tersebut tidak mampu menjawab permasalahan di tengah masyarakat saat ini, maka ilmu tersebut akan ditinggalkan oleh masyarakat.

Dalam hal ini, Affandi menyatakan bahwa terdapat empat ciri-ciri yang biasa ditengarai sebagai indikator untuk melihat tingkat profesionalitas seseorang, yaitu penguasaan ilmu pengetahuan seseorang di bidang tertentu, dan ketekunan mengikuti perkembangan ilmu yang dikuasai; kemampuan seseorang dalam menerapkan ilmu yang dikuasai, khususnya yang berguna bagi kepentingan sesama; ketaatan dalam melaksanakan dan menjunjung tinggi etika keilmuan, serta kemampuannya untuk memahami dan menghormati nilai-nilai sosial yang berlaku di lingkungannya; besarnya rasa tanggung jawab terhadap Tuhan, bangsa dan negara, masyarakat, keluarga, serta diri sendiri atas segala tindak tanduk dan perilaku dalam mengemban tugas berkaitan dengan penugasan dan penerapan bidang ilmu yang dimiliki. ${ }^{16}$

Hasil wawancara dengan Informan I, II, VIII, IX, dan X mengemukakan tentang profesionalisme anggota DPRD menuntut adanya kemampuan seorang anggota DPRD dalam memanfaatkan pengetahuan yang dimilikinya untuk kepentingan semua pihak, sebagai berikut.

“Bentuk atau strategi menciptakan profesionalisme anggota DPRD kota Depok yang ditawarkan tersebut, adalah sesuatu kegiatan yang harus dilakukan secara terintegrasi dan berkesinambungan sebagai sesuatu proses yang berkelanjutan. Pengetahuan dalam hal ini dimaksudkan sebagai pemikiran asosiatif yang menjalin suatu pemikiran dengan kenyataan atau dengan kata lain berdasarkan pengalaman yang berulang-ulang tanpa pemahanan kausalitas hakiki dan universal. Bahwa profesionalisme pegawai, bukan sekedar ditandai oleh penguasaan ilmu pengetahuan (Iptek) semata, tetapi juga sangat ditentukan oleh cara

${ }^{16}$ M. Joko Affandi, "Netralitas dan Profesionalitas Pegawai Negeri Sipil, dalam Wacana Pengembangan Kepegawaian”, Hasil Penelitian, Badan Kepegawaian Negara, Jakarta, 2002, hlm. 13. 
memanfaatkan Iptek tersebut serta tujuan yang dicapai dengan pemanfaatannya. Seorang profesional harus dapat memberi makna dan menempatkan Iptek tersebut pada manfaat yang maksimal bagi dirinya sendiri maupun pihak atau organisasi di mana ia bekerja serta meningkatkan kualitas kehidupan masyarakat. Di samping itu, seseorang yang profesional adalah tercermin pada sikap dan jati diri terhadap profesinya dengan kesungguhan untuk mendalami, menguasai, menerapkan dan bertanggung jawab atas profesinya. Selanjutnya, memiliki sifat intelektual serta mencari dan mempertahankan kebenaran, dan mengutamakan dan mendahulukan pelayanan yang maksimal".

Profesionalisme anggota DPRD merupakan kemampuan yang erat kaitannya dengan pengembangan sumber daya anggota Dewan. Menciptakan profesionalisme dalam konteks makro terkait kepada pengembangan SDM, dan dalam konteks mikronya terkait dengan pengembangan karier. Pengembangan SDM dan pengembangan karier tersebut pada dasarnya bermuara pada berbagai macam pendidikan dan pelatihan, dan diperkaya dengan pengalaman praktik sehari-hari. Pendapat tentang profesionalisme di atas, dapat dipahami bahwa bagi anggota DPRD upaya meningkatkan ilmu pengetahuan adalah dalam kerangka pengembangan SDM anggota DPRD yang bersangkutan serta meningkatkan profesionalismenya.

Selanjutnya sebagai indikator ketiga dalam dimensi sikap profesionalisme anggota DPRD adalah keterampilan (skill). Kepada informan V, VI, VII, VIII, dan IX diajukan pertanyaan terkait profesionalisme Anggota Dewan dapat diwujudkan dengan keterampilan yang perlu dimiliki dalam mengemban tugas kewenangan yang dimiliki dan hasilnya sebagai berikut.

"Bahwa dalam mencapai tingkat profesionalisme anggota DPRD tersebut, perlu diberikan beberapa keterampilan guna menunjang tugas yang diembannya. Keterampilan tersebut antara lain dalam penggunaan teknologi komputer, mengakses (menerima, mengirim berita melalui internet, dll. Selanjutnya, terampil dalam penggunaan bahasa asing misalnya bahasa Inggris, dan terampil dalam bernegosiasi. Dengan demikian, kualitas Anggota Dewan akan semakin tinggi, dan kemampuan profesionalnya juga akan meningkat".

Dalam kaitan ini, Mokoginta menjelaskan bahwa pengetahuan adalah informasi yang dimiliki Anggota di bidang tertentu dan dengan isi (content) yang spesifik. Keterampilan adalah tingkat kemampuan untuk menyelesaikan tugas yang membutuhkan kemahiran fisik atau mental. Selanjutnya Etika profesi dimaksudkan bahwa Anggota sebagai seorang profesional dalam melakukan tugas dan kewajibannya, selalu berkaitan erat dengan kode etik profesi (code of profession) dan 
kode perilaku (code of conduct), yaitu sebagai standar moral, tolok ukur atau pedoman dalam melaksanakan pekerjaan dan kewajiban masing-masing sesuai dengan fungsi dan peran dalam satu organisasi/lembaga yang diwakilinya. ${ }^{17}$

Begitu pula dari hasil observasi menunjukkan bahwa dalam konteks penelitian ini tingkat keterampilan Anggota Dewan juga dicerminkan oleh cara kerja yang baru hasil pengembangan dari keterampilan-keterampilan yang dimilikinya. Cara kerja yang baru bagi Anggota Dewan di sini terdiri atas tiga tingkatan yaitu 1) mencari ide-ide baru, adalah mengembangkan pemikiran-pemikiran baru untuk pengembangan individu dan organisasi serta masyarakat; 2) melakukan perubahan yaitu melakukan sesuatu yang tidak seperti biasanya dengan jalan pengembangan cara kerja baru guna mempercepat dan meningkatkan kualitas kerja;3) merencanakan dan melaksanakan program-program baru, dan dimaksudkan untuk menentukan serta melaksanakan kegiatan-kegiatan yang lebih baik dan berbeda dengan sebelumnya. 4) memacu kreativitas berpikir, adalah cara berpikir lebih baik dari yang sebelumnya.

Berkaitan dengan sikap profesionalisme dapat diwujudkan melalui peningkatan keterampilan Anggota Dewan tersebut, kepada Informan VIII, IX, dan X dilakukan wawancara dan hasilnya adalah sebagai berikut.

“Keterampilan bagi anggota DPRD kota Depok tersebut, juga berupa kemampuan berdiskusi tentang strategi baru dalam memaksimalkan pencapaian tujuan organisasi. Dalam konteks penelitian ini, keterampilan dalam berdiskusi tentang strategi baru dimaksudkan sebagai kemampuan menyampaikan informasi atau pendapat dengan jelas kepada pihak lain, dan membantu mereka untuk memahami informasi atau pendapat yang disampaikan. Dalam kemampuan berdiskusi di sini, terdapat beberapa tingkatan yaitu: 1) mempertahankan perhatian pendengar; 2) berkomunikasi sesuai kebutuhan pendengar; dan 3) memastikan pemahaman pendengar; serta 4) memahami pembicaraan orang lain".

Dijelaskan bahwa kemampuan mempertahankan perhatian pendengar dimaksudkan mempertahankan perhatian pendengar dengan menggunakan teknikteknik analogi, ilustrasi, tekanan suara, dan bahasa tubuh. Berikut adalah kemampuan berkomunikasi sesuai kebutuhan pendengar, yaitu menggunakan katakata, istilah-istilah, contoh-contoh, ilustrasi, analogi, yang sesuai dengan latar belakang, pengalaman dan harapan pendengar. Begitu pula kemampuan memastikan pemahaman pendengar, di sini dimaksudkan melakukan tanya jawab, 
menegaskan kembali apa yang disampaikan terhadap pendengar, serta kemampuan memahami pembicaraan orang lain, adalah berupaya agar dapat menangkap pokokpokok pikiran yang disampaikan oleh orang lain.

Berkaitan dengan sikap profesionalisme Anggota Dewan berupa keterampilan dalam menggunakan peralatan teknologi baru, hal tersebut dimaksudkan bahwa Anggota Dewan diharapkan memiliki kemampuan penguasaan bidang pengetahuan yang terkait pekerjaan sebagai wakil rakyat dengan menggunakan teknologi. Selain itu, Anggota Dewan juga dituntut memiliki kemampuan manajerial serta memiliki motivasi untuk menggunakan dan mengembangkan keterampilannya tersebut untuk disampaikan kepada orang lain termasuk kepada masyarakat. Terkait hal ini, hasil observasi menunjukkan bahwa terdapat beberapa tingkatan dalam penggunaan teknologi, yaitu selalu sadar akan teknologi baru dan secara aktif mengembangkan keterampilan yang dimiliki serta mengembangkan rasa ingin tahu untuk mendapatkan hal terbaru di bidang teknologi.

\section{Sikap Profesionalisme Anggota DPRD dalam Keseharian Hidupnya}

Dimensi tersebut dianalisis di antaranya melalui indikator memiliki komitmen individu terhadap pekerjaannya sehari-hari. Dalam kaitan ini, Informan II, III, IV, dan V mengemukakan sebagai berikut.

“Kami sebagai Anggota Dewan senantiasa berusaha memegang komitmen pada janji serta amanah rakyat yang kami emban. Semua itu terakumulasi pada tugas, fungsi dan tanggung jawab yang wajib dipenuhi serta berupaya komitmen untuk menghindari perbuatan tercela seperti korupsi, manipulasi, dan segala bentuk pelanggaran hukum lainnya sesuai sumpah/janji yang kami ucapkan. Sikap profesional dalam keseharian hidupnya bagi kami sebagai Anggota DPRD, adalah merupakan bentuk penyelenggaraan pelayanan publik yang dapat diuji dari sudut pandang sejauh mana para Anggota Dewan ini mampu melayani masyarakat, dalam arti mampu membuktikan dalam karya nyata yaitu berhasil mewujudkan harapan rakyat, dan hak-hak masyarakat untuk merasakan dan menikmati hasil pembangunan".

Sikap profesionalisme dimaksudkan bahwa Anggota Dewan sebagai profesional, dalam melakukan tugas dan kewajibannya sehari-hari selalu berkaitan erat dengan kode etik profesi dan kode perilaku. Sebagai wakil rakyat, Anggota Dewan wajib menjalankan amanah rakyat yaitu menyampaikan aspirasi rakyat, tidak mengkhianati apa yang telah dijanjikannya saat kampanye. Dalam kaitan ini, Ma'arif mengemukakan bahwa karakteristik anggota organisasi yang profesional adalah: a) memiliki wawasan yang luas dan dapat memandang masa depan; b) memiliki 
kompetensi di bidangnya; c) memiliki jiwa berkompetisi/bersaing secara jujur dan sportif; dan d) menjunjung tinggi etika profesi. ${ }^{18}$

Hasil observasi menunjukkan bahwa perilaku keseharian yang merupakan cermin sikap profesionalisme para Anggota Dewan, adalah sikap tanggap, responsif dan ramah (bukan malah membuat jarak dengan rakyatnya serta sikap angkuh atau sombong/ takabur, dll) dalam menghadapi masyarakat yang harus mereka perjuangkan nasibnya. Sikap hidup keseharian para Anggota Dewan tersebut, adalah ditunjukkan dengan sikap hidup yang mengandung unsur moral, dan moral tersebut memiliki ciri rasional, objektif, tanpa pamrih, dan netral atau tidak memihak (pro rakyat).

Dalam kaitan ini, Muins menyatakan bahwa profesionalisme di dunia kerja bukan sekedar ditandai oleh penguasaan Iptek saja, tetapi juga sangat ditentukan oleh cara memanfaatkan Iptek itu serta tujuan yang dicapai dengan pemanfaatannya itu. Seorang profesional harus dapat: (1) memberi makna dan menempatkan Iptek itu dapat memberikan manfaat yang maksimal bagi dirinya sendiri maupun organisasi atau perusahaan di mana ia bekerja serta meningkatkan kualitas kehidupan masyarakat; (2) mencerminkan sikap dan jati diri terhadap profesinya dengan kesungguhan untuk mendalami, menguasai, menerapkan dan bertanggung jawab atas profesinya; (3) memiliki sifat intelektual serta mencari dan mempertahankan kebenaran; (4) mengutamakan dan mendahulukan pelayanan yang maksimal dalam kualitas maupun kuantitas di atas imbalan jasa, tetapi tidak berarti bahwa jasanya diberikan tanpa imbalan. ${ }^{19}$

Para Anggota Dewan dalam memberikan pelayanan kepada publik telah ditunjukkan dengan tidak melakukan berbagai bentuk tindakan diskriminatif (pilih kasih) terhadap seluruh warga, walaupun tidak seluruh warga memilih Anggota Dewan yang bersangkutan. Dengan demikian, dalam kaitan dengan perilaku keseharian Anggota Dewan yang mencerminkan sikap profesionalisme yang antara lain ditunjukkan dengan memiliki komitmen pribadi atas pekerjaannya, maka organisasi memegang peranan yang sangat penting dalam hal penegakan ketentuan tentang etika profesi berupa kode etik (code of conduct). Hal tersebut merupakan aturan-aturan susila yang ditetapkan serta wajib ditaati bersama oleh semua anggota yang terhimpun dalam suatu profesi tersebut.

\footnotetext{
${ }^{18}$ M.Syamsul Maarif, "Strategi Peningkatan Kompetensi Aparatur Guna Mengantisipasi Kebutuhan Sektor Pelayanan Publik”, Orasi Ilmiah, Bandung, STIA LAN, 2003, hlm. 7.

${ }^{19}$ Sutan Makmur Muins, "Standar Kompetensi Tenaga Kerja Indonesia”, dalam Majalah Manajemen Pembangunan, Nomor 31 Tahun IX, September, LAN, Jakarta, 2000, hlm. 45.
} 
Selanjutnya kepada Informan VII, VIII, IX, dan X berkaitan dengan profesionalisme Anggota Dewan dapat diciptakan dengan sikap profesional dalam keseharian hidupnya berupa menghormati nilai-nilai sosial yang berlaku sebagai berikut.

“Dalam konteks ini, profesionalisme Anggota Dewan dapat diwujudkan dengan menghormati nilai-nilai sosial yang berlaku. Nilai-nilai sosial di sini menekankan pada etika adalah moral yang dipakai sebagai pegangan umum bagi penentuan baik-buruknya perilaku Anggota Dewan atau benar-salahnya tindakan Anggota Dewan dalam keseharian hidupnya. Dengan demikian, etika adalah berkaitan dengan tingkah laku atau perbuatan, suatu tindakan yang dilakukan secara sengaja dalam keadaan sadar, sehingga patut di dalamnya terdapat sanksi hukum/punishment".

Sikap profesional dalam keseharian hidupnya melalui pemahaman etika profesi para profesional seperti para Anggota Dewan ini diharapkan memiliki kualifikasi kemampuan tertentu, misalnya kemampuan kesadaran etis (ethical sensitibility), merupakan landasan utama bagi seorang profesional untuk lebih sensitif dalam memperhatikan kepentingan profesi yang tidak ditujukan untuk kepentingan sendiri (subjektif), tetapi untuk kepentingan yang lebih luas (objektif).

Indikator selanjutnya adalah berkaitan dengan profesionalisme Anggota Dewan dapat terwujud melalui sikap profesional dalam keseharian hidupnya berupa menaati segala peraturan perundang-undangan yang berlaku. Berikut dikemukakan hasil wawancara mendalam terhadap Informan XI, dan XII sebagai berikut.

“Profesionalisme Anggota Dewan dapat dicapai dengan kemampuan menunjukkan sikap profesionalisme dalam kehidupan sehari-hari berupa taat pada peraturan perundang-undangan yang berlaku. Dalam hal ini diperlukan adanya kesadaran dan kesediaan pada diri masing-masing Anggota Dewan secara sukarela menaati semua peraturan dan sadar akan tugas dan tanggung jawabnya. Oleh karenanya para Anggota Dewan wajib mematuhi dan mengerjakan semua tugasnya dengan baik, bukan atas paksaan. Kesediaan adalah suatu sikap, tingkah laku dan perbuatan Anggota Dewan yang sesuai dengan ketentuan organisasi".

Selanjutnya kepada Informan VIII, IX, X, dan XI diajukan pertanyaan berkaitan dengan profesionalisme Anggota Dewan dapat diwujudkan dengan memanfaatkan profesinya untuk kepentingan publik/masyarakat luas, dan hasilnya sebagai berikut.

"Sebagai strategi dalam mewujudkan profesionalisme Anggota Dewan ke depan, maka hal tersebut adalah sesuatu kegiatan yang harus dilakukan secara terintegrasi dan berkesinambungan sebagai sesuatu proses yang berkelanjutan. Oleh karena itu, hasil penelitian ini dapat dijadikan bukti empiris bahwa para 
Anggota DPRD sendiri di Kota Depok serta dukungan dari stakeholders yang lain yaitu masyarakat luas ternyata menghendaki adanya suatu prinsip dasar dalam pelaksanaan profesionalisme Anggota Dewan dapat diwujudkan dengan memanfaatkan profesinya untuk kepentingan publik".

Ditegaskan bahwa untuk meningkatkan perjuangan, pengabdian, kesetiaan dan ketaatan setiap Anggota Dewan kepada negara kesatuan dan Pemerintah Republik Indonesia berdasarkan Pancasila dan Undang-Undang Dasar 1945, maka diperlukan hal-hal sebagai berikut. Pembinaan karakter/watak, memelihara rasa persatuan dan kesatuan secara kekeluargaan, guna mewujudkan kerja sama dan semangat pengabdian kepada masyarakat serta meningkatkan kemampuan, dan keteladanan sebagai Anggota Dewan.

\section{Pelaksanaan Fungsi Legislasi Anggota DPRD Kota Depok}

\section{Fungsi Pembentukan Peraturan-peraturan di Tingkat Daerah}

Hasil wawancara dengan Informan I, II, dan III berkaitan dengan indikator pertama terkait pelaksanaan fungsi legislasi ini adalah adanya ketentuan yang responsif dan akomodatif, sebagai berikut.

“Dalam menghasilkan peraturan perundang-undangan yang responsif dan akomodatif, tidak hanya menjadi pekerjaan pemerintah pusat namun juga secara simultan sampai ke pemerintah daerah. Dalam konteks ini, legislasi (perundangundangan) mengandung makna, bahwa perundang-undangan merupakan proses pembentukan atau proses membentuk peraturan-peraturan negara, di tingkat pusat maupun daerah. Makna selanjutnya bahwa perundang-undangan adalah segala peraturan negara yang merupakan hasil pembentukan peraturan baik di tingkat pusat maupun di tingkat daerah".

Hal senada dikemukakan oleh Marbun, bahwa pada garis besarnya legislatif daerah adalah membuat UU di daerah (Perda), tetapi perkembangan ketatanegaraan yang menuntut perluasan hak dan kewajiban serta fungsi legislatif telah ikut berubah dan berkembang. Dijelaskan bahwa Perda merupakan peraturan perundangan yang secara ketatanegaraan baru diangkat derajatnya sebagai bagian dari tata susunan peraturan perundang-undangan di Indonesia setelah TAP MPR Nomor III/MPR/2000 tentang Sumber Hukum dan Tata Urutan Peraturan Perundang-undangan. ${ }^{20}$ Perda Kota Depok, merupakan produk hukum yang

\footnotetext{
${ }^{20}$ BN. Marbun, DPR Pertumbuhan dan Cara Kerjanya, Pustaka Sinar Harapan, Jakarta, 2006, hlm. 56.
} 
dibentuk bersama antara DPRD kota Depok dengan pihak eksekutif daerah yang dalam hal ini adalah Kepala Daerah.

Dalam hal tertentu, yaitu terkait dengan pelaksanaan Perda Kota Depok tersebut, adakalanya diperlukan pengaturan lebih lanjut yaitu dengan Peraturan Walikota Depok atau Keputusan Walikota Depok. Pembentukan Peraturan Walikota Depok tersebut, tidak memerlukan persetujuan DPRD Kota Depok yang ada kalanya merupakan perintah langsung dari Perdanya sendiri, maupun dalam rangka menindaklanjuti suatu Perda yang telah ditetapkan. Hasil observasi menunjukkan bahwa dalam pembentukan Perda di Kota Depok, dilakukan dengan membentuk panitia legislasi.

Panitia legislasi merupakan alat kelengkapan yang bersifat tetap dan dibentuk oleh DPRD pada masa awal keanggotaan DPRD. Setelah terbentuknya pimpinan DPRD, komisi-komisi, panitia anggaran, panitia musyawarah, dan fraksi. Akhirakhir ini telah disahkan tiga Rancangan Peraturan Daerah (Raperda) menjadi Peraturan Daerah (Perda). Ketiga Perda tersebut adalah Perda Organisasi Perangkat Daerah (OPD), Perda Pembinaan, dan Pengawasan Ketertiban Umum. Semua proses tersebut telah dilaksanakan oleh DPRD Kota Depok dengan baik dan aspiratif serta mengacu pada ketentuan yang ada.

\section{Fungsi Pengendalian dan Pengawasan}

Indikator atas pelaksanaan fungsi ini adalah mengurus urusan rumah tangga, tugas pembantuan serta meminta keterangan pertanggungjawaban, hak anggaran, dan hak mengajukan pertanyaan. Berikut dikemukakan hasil wawancara dengan Informan I, II, dan III.

“Kami sebagai Anggota Dewan telah mengkritik kinerja Pemerintah Kota khususnya Wali Kota Depok sepanjang 2011. Banyak hal yang kurang optimal dari kinerja Pemerintah Kota Depok di berbagai sektor. Hal itu mengakibatkan tidak efisiennya pembangunan dan berdampak pada kesejahteraan rakyat. Sedikitnya ada sepuluh catatan, baik infrastruktur, maupun kesehatan dan pendidikan, misalnya pembebasan lahan fasos fasum pengembang yang belum optimal, optimalisasi aset daerah belum optimal banyak yang belum tercatat, atau masih simpang siur".

Dapat dikemukakan bahwa terkait dengan fungsi pengendalian dan pengawasan, dan berangkat dari paparan di atas, maka sebagai konsekuensi logis dari rumusan tersebut DPRD Kota Depok mengemban tugas pengendalian dan pengawasan jalannya Pemerintah Kota Depok. Anggota Dewan bertanggung jawab melaksanakan salah satu fungsi manajemen Pemerintah Daerah yaitu controlling dan 
supervision. Peraturan telah memberikan kesempatan luas bagi Anggota Dewan guna melaksanakan fungsi pengawasan atas jalannya pemerintahan di daerah.

Hasil observasi menunjukkan bahwa fungsi yang sangat penting tersebut telah dilaksanakan dengan maksimal namun belum sempurna dalam arti belum sepenuhnya memuaskan masyarakat.

Ketentuan yang ada telah membuka dan memberi kesempatan luas kepada Anggota Dewan untuk melaksanakan fungsi pengendalian dan pengawasan atas jalannya pemerintahan daerah, antara lain sebagai berikut. Pertama, bersama-sama dengan Kepala Daerah, mengatur dan mengurus urusan rumah tangga dan tugas pembantuan. Kedua, meminta keterangan pertanggungjawaban Kepala Daerah sekurang-kurangnya sekali setahun, atau apabila perlu oleh DPRD atau Kepala Daerah. Ketiga, melalui hak anggaran, DPRD ikut menentukan Rencana APBD, perubahan APBD dan pengesahan APBD; dan Keempat, melalui hak mengajukan pertanyaan, DPRD dapat menanyakan segala sesuatu yang dianggap penting atas jalannya pemerintahan di daerah.

\section{Fungsi Representasi}

Indikator pertama atas fungsi ini adalah segala tindakan/ aktivitas Anggota Dewan, berikut dikemukakan hasil wawancara dengan Informan VII, VIII, dan IX.

“Kami sebagai Anggota Dewan, adalah merepresentasikan masyarakat tertentu yang diwakilinya. Anggota Dewan harus dan telah berusaha bertindak dan berperilaku sebagai representatif (wakil) untuk setiap tindak tanduknya dalam seluruh aktivitasnya sebagai Anggota Dewan. Anggota Dewan memiliki kedudukan strategis, namun harus diimbangi dengan perbuatan dan hasil kerja yang produktif serta berguna bagi masyarakat yang diwakilinya. Anggota Dewan adalah penyambung suara, duta, penyambung lidah, pelindung dari rakyat yang mempercayakan suara kepadanya melalui pemilihan umum".

Apabila Anggota DPRD tidak memenuhi persyaratan tersebut, maka dapat dibayangkan bagaimana jalannya fungsi DPRD serta nasib rakyat yang diwakilinya tadi. Padahal setiap anggota DPRD walaupun secara organisatoris dapat ditarik atau di recall dari keanggotaannya, namun dalam praktik hal tersebut prosedurnya tidak mudah. UU No. 32 Tahun 2004 pada paragraf ketiga Pasal 42 disebutkan bahwa DPRD mempunyai tugas dan wewenang a. Membentuk Perda yang dibahas dengan Kepala Daerah untuk mendapat persetujuan bersama; b. Membahas dan menyetujui rancangan Perda tentang APBD bersama dengan Kepada Daerah; c. Melaksanakan pengawasan terhadap pelaksanaan Perda dan peraturan perundang-undangan 
lainnya, peraturan kepala daerah, APBD, kebijakan pemerintah daerah dalam melaksanakan program pembangunan daerah dan kerja sama internasional di daerah. Menurut Budiardjo, bahwa terkait Perda tentang Tata Tertib (tatib) DPRD, substansinya masih lemah mengingat produk dari tatib dapat berakibat terhadap masyarakat luas dan/atau Pemda itu sendiri. ${ }^{21}$

\section{Fungsi Memilih dan Menyeleksi}

Terkait dengan fungsi memilih dan menyeleksi dalam dimensi ini dengan indikatornya adalah mengelola dan mengatur pemerintahan, berikut dijelaskan oleh Informan I, II, dan V.

“Kami sebagai Anggota Dewan di Kota Depok memiliki fungsi memilih dan menyeleksi. Hal ini dimaksudkan sebagai konsekuensi logis bahwa Pemerintah daerah adalah Kepala Daerah dan DPRD. Jadi, DPRD terlibat dalam hal-hal yang lain di luar tugas pokoknya sebagai legislator. DPRD telah ikut bahkan dituntut menurut peraturan untuk mengelola serta mengatur pemerintahan daerahnya sesuai bidang tugasnya dan sejalan dengan peraturan yang berlaku".

Hasil observasi menunjukkan bahwa ternyata fungsi tersebut mempunyai peran yang menentukan masa depan suatu daerah. Apabila hal tersebut salah dalam pelaksanaannya atau kurang tepat, maka akan mendatangkan masalah bagi daerah yang bersangkutan yaitu kemungkinan salah urus, pemimpin yang tidak profesional dan lain-lain.

\section{Fungsi Debat}

Keterangan dari Informan IV, VI, dan VII terkait dengan fungsi debat tersebut bahwa:

“Dalam hal fungsi debat tersebut, di antara fungsi DPRD lainnya adalah yang paling populer dan mendapat banyak nama dan jargon. Dalam beberapa hal memang debat di DPRD Kota Depok dapat juga sekali-sekali masuk pada debat berupa mengemukakan pemikiran-pemikiran visioner (brainstrorming), dan dalam debat tersebut adalah ajang berfikir inovatif dan konstruktif untuk kemaslahatan masyarakat. Melalui debat tersebut, dapat ditelusuri latar belakang suatu pemikiran atau konsep dan saling berkaitan faktanya sehingga melahirkan pemahaman atau perumusan yang lebih matang dan lengkap. Dalam pelaksanaannya, fungsi ini telah berjalan dengan baik, terbukti mampu menghasilkan pemikiran yang konstruktif untuk kemaslahatan masyarakat Depok".

${ }^{21}$ Mirian Budiardjo dan Ibrahim Ambong, Fungsi Legislasi dalam Sistem Politik Indonesia, RadjaGrafindo Persada, Jakarta, 1995, hlm. 34. 
Menurut Budiardjo, seperti fungsi DPRD lainnya, maka fungsi debat juga menuntut kualifikasi tertentu dari setiap anggota DPRD. seseorang hanya mungkin berdebat secara produktif apabila memenuhi persyaratan tertentu, antara lain a. kematangan berfikir; b. latar belakang pendidikan yang memadai; c. dapat berfikir logis dan konseptual; d. penguasaan teori dan praktik yang memadai; dan e. dapat berbicara secara komunikatif; serta $f$. menguasai berdebat secara positif. ${ }^{22}$ Dengan demikian, seperti halnya fungsi DPRD lainnya, maka fungsi debat juga menuntut kualifikasi tertentu dari setiap anggota DPRD. Anggota Dewan hanya akan menghasilkan perdebatan secara produktif apabila memenuhi persyaratan tertentu di antaranya telah matang dalam berfikir; mempunyai latar belakang pendidikan yang memadai; Anggota Dewan tersebut mampu berfikir logis dan konseptual; menguasai teori dan praktik yang memadai; mampu berbicara secara komunikatif; serta menguasai teknik berdebat secara positif. Hasil observasi menunjukkan bahwa kriteria-kriteria tersebut dalam suatu perdebatan di lembaga ini sebagian besar telah terpenuhi, artinya bahwa suatu debat di DPRD Kota Depok jarang terjadi adanya debat kusir atau bahkan debat yang tidak relevan.

Menurut Ruslan, dalam pembentukan peraturan perundang-undangan (termasuk pembentukan Perda), pada dasarnya bukanlah pekerjaan yang mudah, karena itu diperlukan orang-orang yang memiliki kapasitas tertentu (bidang ilmu tertentu dan ahli di bidang teknis perancangan). Salah satu hal yang harus dipahami oleh setiap perancang peraturan perundang-undangan (legal drafting) adalah merumuskan secara baik dan benar landasan peraturan yang dibentuk, sehingga mampu mencerminkan peraturan yang baik. ${ }^{23}$

\section{Penutup}

Dari uraian di atas, dapat disimpulkan, pertama, profesionalisme Anggota DPRD Depok telah cukup baik, hal ini ditunjukkan dalam: 1) perilaku kerjanya yang tidak hanya didukung ilmu pengetahuan yang dimilikinya semata, namun juga ditentukan oleh cara memanfaatkan ilmu pengetahuan pada tujuan organisasi yang telah ditetapkan. Di samping itu, Anggota Dewan senantiasa berusaha memegang komitmen pada janji-janji yang pernah disampaikan kepada masyarakat, yaitu

\footnotetext{
${ }^{22}$ Ibid, hlm. 34

${ }^{23}$ Ahmad Ruslan, Pembentukan Perundang-undangan yang Berkualitas, Tidak Diterbitkan, Handout, 2006, hlm. 52
} 
berupa karya nyata di antaranya mampu menghasilkan beberapa regulasi guna mewujudkan kemaslahatan dan kesejahteraan masyarakat. 2) Anggota Dewan senantiasa berusaha menghindari perbuatan-perbuatan tercela seperti korupsi, kolusi dan nepotisme (KKN) serta segala bentuk pelanggaran hukum lainnya dengan berpegang pada sumpah atau janji yang pernah diucapkan. 3) sikap profesionalnya dalam kehidupan sehari-hari, yaitu dengan menghormati nilai-nilai sosial yang berlaku, memanfaatkan dan mendarmabaktikan profesinya untuk kepentingan masyarakat, senantiasa mengikuti perkembangan disiplin ilmu yang dimiliki, sehingga mampu berfikir visioner serta semakin terampil dalam memecahkan berbagai persoalan yang menjadi tugas dan tanggung jawab sebagai amanah rakyat yang harus dipenuhi dalam bentuk karya nyata.

Kedua, pelaksanaan fungsi legislasi Anggota DPRD Kota Depok dan Pemerintah Kota Depok terkait hal-hal: 1) pembentukan peraturan perundang-undangan di tingkat daerah telah dijalankan dengan baik, hal tersebut ditunjukkan bahwa semua prosedur penyusunannya telah sesuai dengan ketentuan serta menghasilkan beberapa ketentuan yang kini berlaku, dan bersifat aspiratif yaitu mencerminkan aspirasi atau kehendak masyarakat Kota Depok; 2) pelaksanaan fungsi representatif Anggota Dewan, telah dijalankan secara maksimal yaitu ditunjukkan dengan bertindak dan berperilaku yang mampu mencerminkan sebagai representatif (wakil) rakyat secara keseluruhan di Kota Depok; 3) pelaksaaan fungsi memilih dan menyeleksi bagi Anggota Dewan, yang indikatornya: a) bersama-sama dengan Pemerintah Kota Depok mengelola dan mengatur pemerintahan di Kota Depok, hasil penelitian menunjukkan bahwa fungsi tersebut telah dijalankan Anggota Dewan dengan baik dan sejalan dengan peraturan yang berlaku. b) Fungsi debat yang dijalankan Anggota Dewan di Kota Depok telah berjalan dengan baik, hal ini terbukti mampu menghasilkan pemikiran-pemikiran konstruktif untuk kemaslahatan dan kesejahteraan masyarakat secara keseluruhan di Kota Depok.

Agar profesionalisme Anggota DPRD Depok dapat terus ditingkatkan, maka: a) diperlukan tindakan konkrit antara lain perlunya diadakan berbagai jenis pelatihan sesuai kebutuhan nyata para Anggota Dewan (training need assessment) dalam menjalankan fungsi legislasi, sehingga baik kemampuan, pengetahuan, dan keterampilannya akan meningkat serta ditunjang dengan perilaku/moral yang terpuji dan amanah; b) agar para Anggota Dewan di Kota Depok semakin memahami substansi dan mekanisme kerjanya di bidang legislasi, sehingga tercapai kinerja 
(performance) maksimal baik secara kuantitatif maupun kualitatif. Di samping itu, perlu dukungan sarana dan prasarana secara maksimal sehingga kinerja (performance) organisasi dapat terus ditingkatkan serta kesejahteraan masyarakat Kota Depok dapat segera diwujudkan.

\section{Daftar Pustaka}

Azhari, Negara Hukum Indonesia, Analisis Yuridis Normatiftentang Unsur-Unsurnya, UI Press, Jakarta, 1995.

Affandi, M, Joko, Netralitas dan Profesionalitas Pegawai Negeri Sipil, dalam Wacana Pengembangan Kepegawaian, (Hasil Penelitian), Badan Kepegawaian Negara, Jakarta, 2002.

Budiardjo, Mirian dan Ambong, Ibrahim, Fungsi Legislasi dalam Sistem Politik Indonesia, Radja Grafindo Persada, Jakarta, 1995.

Herman, "Analisis terhadap Faktor - faktor yang Mempengaruhi Profesionalisme PNS“ makalah, Puslitbang BKN, Jakarta, 2003.

Kadarisman, Muh, Pemberdayaan terhadap Kinerja Anggota DPRD Kota Depok, dalam Jurnal Mimbar Hukum UGM, Vol. 24 Nomor 2, Juni 2012.

Marbun, BN, DPR Pertumbuhan dan Cara Kerjanya, Pustaka Sinar Harapan, Jakarta, 2006.

Maarif, M, Syamsul, "Strategi Peningkatan Kompetensi Aparatur Guna Mengantisipasi Kebutuhan Sektor Pelayanan Publik", Orasi Ilmiah, Bandung, STIA LAN, 2003.

Manan, Bagir, Menyongsong Fajar Otonomi Daerah, Pusat Studi Fakultas Hukum UII, Yogyakarta, 2001. , Beberapa Masalah Hukum Tata Negara Indonesia, Alumni, Bandung, 2001. Asas-Asas Pembentukan Peraturan Perundang-undangan yang Baik, Raja Grafindo Persada, Jakarta, 2009.

Mertodikusumo, Sudikno, Mengenal Hukum Suatu Pengantar,Liberty, Yogyakarta, 2003.

Muins, Makmur, Sutan, "Standar Kompetensi Tenaga Kerja Indonesia", dalam Majalah Manajemen Pembangunan, Nomor 31 Tahun IX, September, LAN, Jakarta, 2000.

Mokoginta, A. Urip, "Konsep dan Pengalaman LPT UI dalam Rekrutmen Pegawai", Laporan Hasil Diskusi Panel Reformasi Kepegawaian, Pusat Penelitian dan Pengembangan BKN, Jakarta, 2002.

Konsep dan Pengalaman LPT UI dalam Rekrutmen Pegawai, Laporan Hasil Diskusi Panel Reformasi Kepegawaian, Pusat Penelitian dan Pengembangan BKN, Jakarta, 2002. 
Ruslan, Ahmad, Pembentukan Perundang - undangan yang Berkualitas, Handout, Tidak Diterbitkan, 2006.

Surahmad, Winarno, Metodologi Research-1, Alumni, Bandung, 1983.

Widjaja, HAW, Penyelenggaraan Otonomi di Indonesia dalam Rangka Sosialisasi UU Nomor 32 Tahun 2004 tentang Pemerintahan Daerah, Penerbit Raja Grafindo Persada, Jakarta, 2005. 